$* * *$

23 April 2012

\title{
A Girl in Wolf's Clothing
}

Language is an integral part of human existence, but at the same time language is more than just what allows us to reach out to others; in many respects it defines who we are and who we may reach out to. If you take a closer look you can see language is the marker of your social identity and your place in society. Changing your language is a serious matter, because it if you change your language, than your social identity is invariably affected in some way, be it for better or worse. Once you change your social identity you cannot entirely go back to the way you were before.

Jean George's novel Julie of the Wolves is a perfect example of how language can change one's social identity for both good and bad. In this novel a young Eskimo girl named Miyax runs away from home after nearly being raped by her husband, and takes shelter with a pack of wild wolves that accept her as one of their own. In order to be accepted Miyax must learn the wolves' way of communicating - a silent language known as wolf speech. In doing so she ultimately leaves her human identity behind. Language is viewed by the author as a marker of intelligence, and because the wolves do have their own language - albeit a less advanced one that relies mostly on body language- it partially bridges the intellectual gap between animal and human in the book which allows Miyax to communicate with the wolves.

Often animals are used a marker for inhuman or socially unacceptable behavior, and are treated as the lowest rung on the social hierarchy. Still, because animals have a place on humanity's social hierarchy, it possible for a human to become an animal in a 
social respect. A change in language can sometimes be what causes this fall in the social hierarchy. In both Julie of the Wolves and "Dog Words" the authors use human-animal interactions as an allegory of the protagonist falling to the status of a 'social animal'. In both cases the protagonist's downfall is caused by changing their language. At first their new language life-saving - the Bedouin learns to imitate a dog's barking to encourage the dogs to lead him out of the desert, while Miyax, lost on the tundra learns uses wolf speech to gain the wolves' acceptance. For both Miyax and the lost Bedouin, their original plan was to on temporarily take on an animal identity. "One must bark in order to find one's way; in order to become human one must first turn into a dog," (Kilito 2). To Miyax and the Bedouin becoming an animal is an intermediate stage between being lost in the wild and reuniting with humanity.

Although Miyax and the Bedouin's new languages are initially life-saving, in end they cause the downfall of both protagonists. By taking on the language of animals, they undergo a permanent social transformation into an animal. Consequently they are shunned by their respective societies once they return to humanity, because their peers don't want to associate with a social animal, which in essence is an untouchable. In "Dog Words" the authors makes the Bedouin's newly acquired dog language permanent as an allegorical way to show the effects of changing one's social identity. This linguistic barrier is symbolic of the social distance that has grown between the tribe and the Bedouin, who now dwells on the bottom of the social hierarchy. It will forever keep him from being fully human, but because he is still allowed to live among the tribe, neither can he be fully dog. For Miyax, her fate is similar. Though she does not physically loose the ability to speak Yupik - the language of her tribe - in the end she is unable to return to 
her own father, whom symbolizes a normal human existence. Instead she opts for life on the tundra, though by this point her wolf family has disappeared, leaving Miyax utterly alone. "The hour of the wolf and the Eskimo are over, (George 170)." Miyax can neither be a human nor wolf now, like the Bedouin her identity is ambiguous in the end, eternally trapped between two, conflicting alternatives.

Language can be the building block of new, better social identity as well. When one is coming from a bad social identity or low place in the social hierarchy, sometimes learning a new way to communicate can make all the difference. In his story "Learning to Read and Write", Fredrick Douglass experiences the enlightenment of learning to read and write, which contributed to his rise from a mere slave to the successful, freeman and writer he would become later in life. When language is used to build a better social identity, language is seen as enlightenment. It celebrates an individual's path to connecting with new social circles rather than emphasizing the ones they leave behind, such as in the Bedouin's case. Language is one of the main things that keep social groups together. So taking on the language of a foreign social circle or class makes acceptance into the new group easier. Fredrick Douglass was born into one of the lowest possible social classes of his time - black slaves, and learning to read and write was the only way for him to move to a higher class. For those with low ascribed status (the social class you are born into often based on race, class, gender, or sexual orientation) learning the language of those of higher social status is sometimes the only way to move up through the social hierarchy. For example, Fredrick reads about how a slave talked his way to freedom. "The slave was made to say some very smart and impressive things in reply to his master - things which had the desired though expected effect; for the conversation 
resulted in the voluntary emancipation of the slave on the part of the master,"(Douglass 131). Knowing the language of one's higher-ups makes one stand out and more able to change social class, than those who do not.

What is interesting about Miyax's story is that the language she learns allows her to become a part of a lower social class - the wolves, which have an even lower status that Fredrick's former slave status because they are animals. For Fredrick language is his opportunity to rise through social hierarchy, for doing so will allow him more opportunities in life and to have a bigger impact in society. Miyax's motivation is the opposite; she sees living with wolves as a way to escape human society, not become a better part of it. Learning wolf speech ultimately gives Miyax the freedom to not return to her former society.

Language can cause one to move into new social circles, but it can also help one preserve their social identity, even in the face of opposition. Smaller minorities often find themselves under pressure to assimilate to the dominant language of their area or country. If we take a look at Anzaldua's "How to Tame a Wild Tongue" we see how she struggles against the discrimination Chicano Spanish speakers face from both English speakers and fellow Mexicans for speaking what others deem a 'bastard language'. Anzadula sees linguistic assimilation as a threat only if you choose to give in. Even if you live in a divided community, the decision to assimilate or not rests with you. "Until I can take pride in my language, I cannot take pride in myself. I am my language," (Anzadula 89). In her eyes there is no way to run away from this discrimination; you can only stand strong in the face of opposition.

Miyax find herself in a similar situation, though she handles the threat of 
assimilation differently than how Anzadula does. Miyax’s Yupik-speaking village once valued the traditional Eskimo way of life. However when Westernization came to her village, the Eskimo ways and language fell out of practice and English became the standard language, much to Miyax's dismay. Like Anzadula, Miyax uses language as a way of reinforcing her social identity and as a way to defy linguistic assimilation into the dominant language. Miyax's escape to the tundra and learning the language of wolves is her way to escape the linguistic assimilation. The wolf pack can be seen as a symbol of hope of preserving the Eskimo way of life against Westernization and English. Miyax sees assimilation as an inevitable force. She believes that only by escaping the community altogether can she preserve her identity from it. To her, assimilation is not a personal choice to give into pressure, but a natural consequence of living in a community where your language or culture is not the dominant one.

Language is more than just a tool of communication; it defines us and makes us a part of our society. If who we are is so dependent on language, it is much easier to see how identity can change so readily. African slaves can become powerful orators, and an Eskimo girl can become a wolf, all through the power of language. Language can both keep us together, or divide us apart, and perhaps by understanding what a powerful thing language is we can better learn how to use it. 


\section{Work Cited}

George, Jean. Julie of the Wolves. New York: HarperCollins Children's Books, 1972.

Print 
Lauren Fairnot

English 125-49

$4 / 23 / 12$

\section{Lauren Fairnot's Exit Letter}

This year has taught me to not look on my past writing with shame or arrogance, but to see each and everything I write as important to understanding myself as writer. I've learned that in every essay I write there is a lesson to be learned. English 125-49 has given me the chance to understand myself more as a writer; for each of the four essays I had to call upon a different facet of my writing style, and learn to write in ways that I had never used before.

The first essay tested my ability to use a real life situation, report it factually but with enough originality to make in an interesting piece. This paper couldn't just be another, dull narrative about my time in Chinese 101. First I had to get a good enough summary of the class; that was easy and familiar enough. Next I had to understand how the class worked from the teacher's perspective; that was the most difficult part of writing Paper 1. In the end I was very pleased with the result, and now know that no matter what angle I have to look at an experience, I can write about it just as strongly.

The second essay was definitely the most difficult of them; I ended up having to write three separate drafts before I got the end result. What was so difficult about this paper was that for the first time I was being asked to analyze the processes of writing itself, rather than explore an established argument like I was used to. However, in the end it really showed me an entirely different way to approach a paper, and helped me to learn some of the most important processes of writing - considering your audience, writing 
within a certain genre or field of knowledge, and to consider how to transition between ideas effectively. Most importantly, Paper 2 taught me that no matter how shabby or poorly written the first (or second) draft may seem, with hard work the final draft will always show the efforts of all my hard work!

Paper 3 and Paper 4 were perfect opportunities to reconnect with two of my favorite childhood books - Redwall and Julie of the Wolves, respectively. However, unlike in the past where I would simply explore established arguments about a book, now it was my job to come up with my own analysis. That was one big difference between English 125-49 and my AP English class in high school - in English 125-49 it was all about coming up with your own argument, not adding onto preexisting ones. A very important lesson I learned from Paper 3 and 4 was that if I use a novel in my paper, I have to be careful not to put too much plot summary because it will take away from my overall argument. Using a novel is just fine, but plot summary will turn my essay into a mere book report. That was probably my biggest flaw in Paper 3, and why I readily tossed away my first draft of Paper 4 - which was about 90\% plot summary.

To me, writing is much more than simply something I do for class - it is who I am in many regards. As an author of a few unpublished fantasy novels, I treasure my old stories. They are hidden gems in my writing past, which I can constantly turn to for inspiration. Now I've learned that everything I write is precious, and that if I am ever going to be the bestselling novelist of my dreams, then I need to use every bit of writing I can to improve my writing style. I have truly enjoyed my experience in English 125-49, and thank you Mr. Runyan for this opportunity to learn more about myself as a writer. 
- Sincerely,

Lauren Fairnot 